\title{
Evaluation research using astronomy theatre suggests good promise for young Spanish- origin women to choose science majors
}

\author{
Christopher Corbally ${ }^{1, *}$, and Margaret Boone Rappaport ${ }^{2}$ \\ ${ }^{1}$ Vatican Observatory, University of Arizona, Tucson, AZ 85721, USA \\ ${ }^{2}$ The Human Sentience Project LLC, 400 E. Deer's Rest Pl., Tucson AZ 85704, USA
}

\begin{abstract}
We report evaluation findings and best practices from a morning of research with senior class students at an all-Spanish-origin, secondary school in the southwest United States. We found a jump in interest toward science for the women who self-identified as humanities students, and over the morning, surprisingly, this affected their remembrance of previous attitudes. Our results for this and other evaluations corroborate that experiential activities involving one-to-one or group activities are useful in attracting high school and college students to the sciences, especially young women. These results also pointed toward best practices.
\end{abstract}

\section{Addressing the manpower problem}

There is a manpower problem in the low percentages of females and Spanish-origin people in the fields of astronomy and astrobiology. The National Research Council's 2010 Decadal Survey emphasizes the social utility of astronomy, which increases its appeal. There is an advantage from knowing colleagues well because the astronomy workforce worldwide is not large. These two factors may help to correct the manpower problem, especially since the minority students involved, according to research by us and others, respond to social factors in selecting a major, and sticking with it

We have developed 12 instructional theatre packages (Figure 1) that introduce astronomy concepts in 5-minute scripts featuring two players in scientist or other spacescience roles. Packages include Keywords, Preliminary Study Topics, Follow-Up Discussion Questions, and suggestions for staging and costumes. Our goal was to evaluate this form of interactive instruction to interest young adults in astronomy and astrobiology.

\footnotetext{
* Corresponding author: corbally@as.arizona.edu
} 


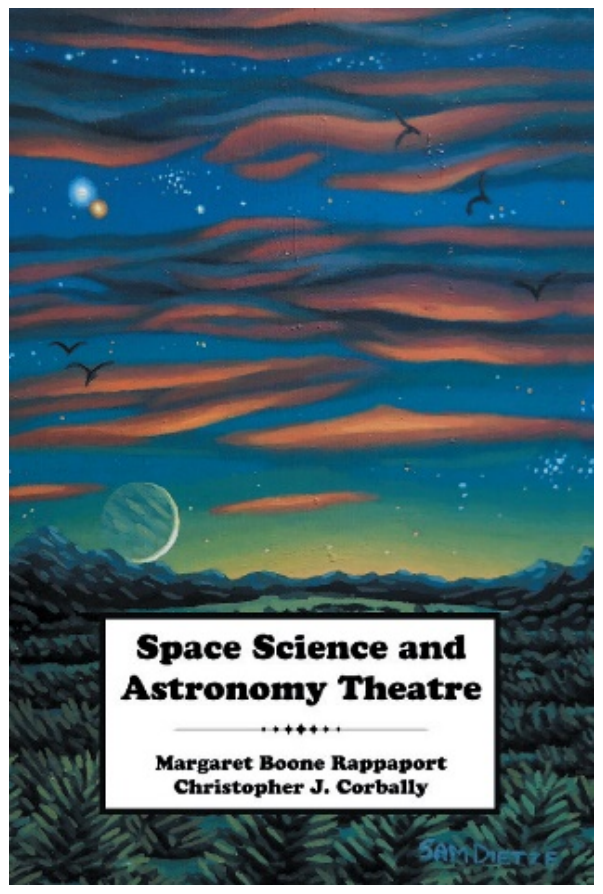

Fig. 1. Cover of our book, Space Science and Astronomy Theatre, containing 12 instructional theatre packages (for more information go to, http://TheHumanSentienceProject.org).

\section{The evaluation scenario}

For the evaluation, we spent the better part of a morning with 56 members of the senior class of an American, all-Spanish-origin, private, secondary school in the southwest United States. Forty-six percent were male and 54 percent were female. The average age was 18 years. About 95 percent of the students went to college. Therefore, we felt it was a good place to test a new educational tool by determining the change in their attitudes toward astronomy and science.

We thought there might be students ready to enter astronomy or other science fields, but who were undecided. We thought it was important to identify students in a special drama program, and students who self-identified as "mainly humanities" or "mainly science." Students could check one or both. Because of this, we saw a broad overlap in their interests, with a modest skewing toward the humanities for females-but, nothing like we expected. Note we asked in two ways on two forms. Not everyone answered, so figures do not total to 56 (Table 1).

We saw that, of the 13 males who identified themselves as mainly math/science students, 3 of them also identified themselves as humanities students. Of the 12 females who identified themselves as math/science students, 3 of them did the same. In other words, about a quarter of the self-identified science students were also sufficiently interested in humanities to call themselves humanities students, too. We conclude there were students who could follow either a humanities or math/science track. In a motivated group of students like we found at this private high school, interest in science and humanities did not eliminate each other. 
Table 1. The self-reporting of the students

\begin{tabular}{|c|c|c|c|}
\hline & Males & Females & All Checks \\
\hline \multicolumn{4}{|l|}{$\begin{array}{l}\text { Self-Report } \\
\text { Question } 1 .\end{array}$} \\
\hline I am a drama student. & 6 & 6 & 12 \\
\hline $\begin{array}{l}\text { I think of myself as a } \\
\text { math or science } \\
\text { student. }\end{array}$ & 13 & 12 & 25 \\
\hline $\begin{array}{l}\text { I think of myself as a } \\
\text { humanities student. }\end{array}$ & 9 & 13 & 22 \\
\hline \multicolumn{4}{|l|}{$\begin{array}{l}\text { Self-Report } \\
\text { Question } 2 .\end{array}$} \\
\hline \multicolumn{4}{|c|}{ (The following are included in the numbers above.) } \\
\hline $\begin{array}{l}\text { I think of myself as a } \\
\text { science and } \\
\text { humanities student. }\end{array}$ & 3 & 3 & 6 \\
\hline $\begin{array}{l}\text { I am a drama student } \\
\text { and I think of myself } \\
\text { as mainly a science } \\
\text { student. }\end{array}$ & 0 & 2 & 2 \\
\hline $\begin{array}{l}\text { I am a drama student } \\
\text { and I think of myself } \\
\text { as mainly a } \\
\text { humanities student. }\end{array}$ & 5 & 3 & 8 \\
\hline
\end{tabular}

\section{The evaluation}

We followed the presentation approach of our first three instructional packages. The students prepared by researching each of the three worksheets which gave "Keywords" and "Questions for Investigation Before the Script." Then, we performed each script for the students, and led the "Discussion Questions for Use After the Script." All three scripts were stories about supernovae: In $1054 \mathrm{AD}$ (the sighting of the supernovae forming the Crab Nebula); in 2054 AD (a near-future, fictional, Eta Carinae supernova); and in 3054 AD (a fictional Cassiopeian supernova in the more distant future).

The data collection form (Figure 2) had four questions with a 5-level scale of response, from 1 ("Not interested at all") to 5 ("Extremely interested"), and 1 ("Affected very negatively") to 5 ("Affected very positively"). We used these forms once at the beginning, and then once after each of the three script performances. The design was one of pre/post with repeated measures. 
Please fill in your Stud ent Number:

(TIME

Please mark the four scales on this page quickly, giving your first reaction. Here is an E XAMPLE:

Mark here

$\rightarrow$

\begin{tabular}{|c|c|c|c|c|}
\hline & & $\mathrm{X}$ & & \\
\hline $\begin{array}{l}\text { Extremely } \\
\text { Interested }\end{array}$ & $\begin{array}{l}\text { Somewhat } \\
\text { Interested }\end{array}$ & $\begin{array}{l}\text { Neither } \\
\text { interested nor } \\
\text { disinterested }\end{array}$ & $\begin{array}{l}\text { Probably not } \\
\text { interested }\end{array}$ & $\begin{array}{l}\text { Not interested } \\
\text { at all }\end{array}$ \\
\hline
\end{tabular}

(1) In the past, how interested have you been in a college major or a career in math or science?

\begin{tabular}{|l|l|ll|ll|}
\hline$\rightarrow$ & & & & \\
Mark here & $\begin{array}{l}\text { Extremely } \\
\text { Interested }\end{array}$ & $\begin{array}{l}\text { Somewhat } \\
\text { Interested }\end{array}$ & $\begin{array}{l}\text { Neither } \\
\text { interested nor } \\
\text { disinterested }\end{array}$ & $\begin{array}{l}\text { Probably not } \\
\text { interested }\end{array}$ & $\begin{array}{l}\text { Not interested } \\
\text { at all }\end{array}$ \\
\hline
\end{tabular}

(2) At this moment, how interested are you in a college major or a career in math or science?

\begin{tabular}{|c|c|c|c|c|c|}
\hline $\begin{array}{l}\text { Mark here } \\
\rightarrow\end{array}$ & 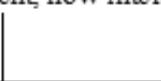 & - & 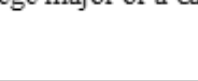 & 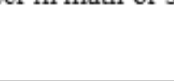 & \\
\hline & $\begin{array}{l}\text { Extremely } \\
\text { Interested }\end{array}$ & $\begin{array}{l}\text { Somewhat } \\
\text { Interested }\end{array}$ & $\begin{array}{l}\text { Neither } \\
\text { interested nor } \\
\text { disinterested }\end{array}$ & $\begin{array}{l}\text { Probably not } \\
\text { interested }\end{array}$ & $\begin{array}{l}\text { Not interested } \\
\text { at all }\end{array}$ \\
\hline
\end{tabular}

(3) You were given some worksheets before today - Skit Day.

Was your interest in science and math affected by your home work with the questions?

\begin{tabular}{|c|c|c|c|c|c|}
\hline \multirow{2}{*}{$\begin{array}{l}\text { Mark here } \\
\rightarrow\end{array}$} & & & & & \\
\hline & $\begin{array}{l}\text { Affected very } \\
\text { positively }\end{array}$ & $\begin{array}{l}\text { Affected } \\
\text { somewhat } \\
\text { positively }\end{array}$ & $\begin{array}{l}\text { Affected } \\
\text { neither } \\
\text { positively nor } \\
\text { negatively }\end{array}$ & $\begin{array}{l}\text { Affected } \\
\text { somewhat } \\
\text { negatively }\end{array}$ & $\begin{array}{l}\text { Affected very } \\
\text { negatively }\end{array}$ \\
\hline
\end{tabular}

(4) So far, has your interest in science and math been affected by today's activities?

\begin{tabular}{|c|c|c|c|c|c|}
\hline \multirow{2}{*}{$\begin{array}{l}\text { Mark here } \\
\rightarrow\end{array}$} & & & & & \\
\hline & $\begin{array}{l}\text { Affected very } \\
\text { positively }\end{array}$ & $\begin{array}{l}\text { Affected } \\
\text { somewhat } \\
\text { positively }\end{array}$ & $\begin{array}{l}\text { Affected } \\
\text { neither } \\
\text { positively nor } \\
\text { negatively }\end{array}$ & $\begin{array}{l}\text { Affected } \\
\text { somewhat } \\
\text { negatively }\end{array}$ & $\begin{array}{l}\text { Affected very } \\
\text { negatively }\end{array}$ \\
\hline
\end{tabular}

Fig 2. Evaluation forms for times zero, 1, 2, and 3 


\section{Results}

Table 2 shows the change in mean scores for the supernovae scripts. If the sample had been larger, we would have conducted t-tests or an analysis of variance for a repeated measures design, but we felt a total population of 56 was insufficient for this.

Table 2. Change in student interest in math/science after script performances (using mean change of rank order scores)

\begin{tabular}{|c|c|c|c|c|}
\hline $\begin{array}{l}\text { Change in Student } \\
\text { interest in Math/ } \\
\text { Science After Script } \\
\text { Performances }\end{array}$ & $\begin{array}{c}\text { After } \\
\text { Script \#1 } \\
\text { Time }_{1}\end{array}$ & $\begin{array}{c}\text { After } \\
\text { Script \#2 } \\
\text { Time }_{2}\end{array}$ & $\begin{array}{c}\text { After } \\
\text { Script \#3 } \\
\text { Time }_{3}\end{array}$ & $\begin{array}{c}\text { From } \text { Time }_{0} \\
\text { to } \mathrm{Time}_{3}\end{array}$ \\
\hline $\begin{array}{l}\text { Question } 2 . \\
\text { At this moment, how } \\
\text { interested are you in } \\
\text { math/science? }\end{array}$ & 0.08 & 0.00 & 0.13 & 0.21 \\
\hline $\begin{array}{l}\text { Question } 4 . \\
\text { Has your interest in } \\
\text { math/science been } \\
\text { affected by today's } \\
\text { activities? }\end{array}$ & 0.13 & 0.14 & 0.18 & 0.45 \\
\hline
\end{tabular}

\subsection{Crossover by humanities students}

We suspected there might be "crossover" opportunities especially for young Spanish-origin women who self-identified as "humanities" students. This proved true (Table 3, last row, column 3$)$. But the entry in row 3 , column $3(-0.25)$ shows that the jump in their interest affected their remembrance of previous attitudes toward science! Recall of PAST feelings became MORE negative as the morning of astronomy theatre progressed. We were surprised.

If the students were recalling their past interest in science, all of their remembrances should have remained the same at all time points, but they did not. We concluded that, because the humanities students saw their present interest in science as newly positive, they perceived their past interest as progressively worse. In other words, in contrast to the past, they were experiencing greater interest in science after a morning of astronomy theatre. These misperceptions of past interest in science are important. They show that levels of interest in science can change. In this group, humanities students may have benefitted from the astronomy script performances more than the math/science students. This is supported by the fact that the mean assessment of being "affected by today's activities" was much greater for humanities students than for math/science students $(0.56$ vs. 0.21 in last row of Table 3). 
Table 3. Overall change in student assessment of past interest in science, and how much the script performances event affected them

\begin{tabular}{|l|c|c|c|}
\hline & All & $\begin{array}{c}\text { Self-Identified } \\
\text { "Mainly Humanities" } \\
\text { Responders } \\
\text { (mostly female) }\end{array}$ & $\begin{array}{c}\text { Self-Identified } \\
\text { "Mainly } \\
\text { Math/Science" } \\
\text { Responders }\end{array}$ \\
\hline $\begin{array}{l}\text { Number } \\
\begin{array}{l}\text { Their perception of } \\
\text { past interest in } \\
\text { science (Q 1) }\end{array}\end{array} \quad-0.07$ & 16 & 19 \\
\hline $\begin{array}{l}\text { Assessment of how } \\
\text { much they were } \\
\text { affected (Q 4) }\end{array}$ & 0.45 & -0.25 & 0.05 \\
\hline
\end{tabular}

\subsection{Overall positive change}

Table 4 gives an overall picture of the different groups of students, their initial interest in math/science, and the change in that interest in the course of the morning. The students in the Gung Ho Group were interested in science and math. A second line of that Group is included for those "interested", but showing "no change".

A total of 53.6 percent showed a positive change in orientation to science and math by the end of the Astronomy Theatre presentations. For all these 30 of 56 students, their four scores in response to Question 4 moved in a positive direction, from the beginning to the end of the morning. A total of seven students had scores that declined, and 19 students had scores that showed no change (including already-committed, self-identified science students, who could have led some of the discussion).

By the end of the morning, interest in science as a college major or a career was expressed by 41 of 56 students, or 73 percent of all students participating that day. Note that 16 students (28.6 percent of all students) who expressed this interest in science had checked themselves as "mainly humanities" students. Again, there is a strong overlap in interest in science and the humanities, among these generally good students. 
Table 4. Groups of students by their interest in science and their response to the scripts

\begin{tabular}{|c|c|c|c|c|c|c|}
\hline Group & $\#$ & $\begin{array}{l}\text { Interested in } \\
\text { Math/Science } \\
\text { Major or } \\
\text { Career? }\end{array}$ & $\begin{array}{l}\text { Change in How } \\
\text { Interest in } \\
\text { Math/Science } \\
\text { Affected by } \\
\text { Scripts Event }\end{array}$ & $\mathrm{D}$ & $\mathrm{M} / \mathrm{S}$ & $\mathrm{H}$ \\
\hline \multirow{2}{*}{ Gung Ho Group } & 25 & Interested & Positive Change & 4 & 14 & 12 \\
\hline & 10 & Interested & No Change & 1 & 5 & 3 \\
\hline $\begin{array}{l}\text { Solid Humanities } \\
\text { Group }\end{array}$ & 6 & Not Interested & No Change & 2 & & 3 \\
\hline $\begin{array}{l}\text { Problem Science } \\
\text { Group }\end{array}$ & 6 & Interested & Decline & 1 & 5 & 1 \\
\hline \multirow{4}{*}{$\begin{array}{l}\text { Open to Change } \\
\text { Group }\end{array}$} & 4 & Not Interested & Positive Change & 2 & 1 & 2 \\
\hline & 3 & Neutral & No Change & & & 1 \\
\hline & 1 & Not Interested & Decline & & 1 & 1 \\
\hline & 1 & Neutral & Positive Change & 1 & & \\
\hline All & 56 & & & & & \\
\hline \multicolumn{4}{|c|}{$\begin{array}{l}\text { Optional self-reports: } \\
\text { D = Drama student } M / S=\text { Mainly math/science } \\
\mathrm{H}=\text { Mainly humanities }\end{array}$} & \multicolumn{3}{|c|}{$\begin{array}{l}\text { Check marks } \\
\text { above do not } \\
\text { sum to numbers } \\
\text { of students. }\end{array}$} \\
\hline
\end{tabular}

\section{Best practices}

Finally, both quantitative results from our data collection instrument, and qualitative impressions from students and teachers indicated the "Best Practices" in Table 5. 
Table 5. Best practices for instructional use of astronomy \& astrobiology performance scripts with college \& high school students
Best Practice:
Take-home worksheets are useful and accepted by students, if not too long.
Best Practice:
Choose a 2- or 3-hour time period, for maximum effect and to allow time for student questions.

Best Practice:

A selection of three astronomy script performances is best, because reactions to individual scripts vary among students.

Best Practice:

Prepare for students who can "go either way" (toward humanities or science).

Best Practice:

Humanities students are well worth encouraging in the sciences, especially females (who may have selected "humanities" by default) or males (who self-identify as both a "science" and "humanities" student).

Best Practice:

Students cluster into types, and the types are important for planning.

For example, instructors can interest already-committed science students by letting them lead keyword definitions or follow-up discussion.

\section{Summary}

To summarize, 73 percent of seniors showed an interest in a science-math major or career, after performances of three astronomy theatre scripts.

(1) There was already a broad overlap in student interest in science-math and humanities, for both sexes;

(2) There was an upswing in interest in science-math, and affectedness by the script performances, of "humanities" responders, whose majority were women; and

(3) There was a general openness to change from humanities to science, as discussed elsewhere in the literature [1].

\section{References}

1. J. Mervis, Science 343, 125 (2014) 